\title{
Pemanfaatan Gulma Siam (Chromolaena odarata L.) Sebagai Adsorben Logam Timbal
}

Erni Mohamad', Intan J. Oputu', Julhim S. Tangio ${ }^{1}$

${ }^{1}$ Program Studi Pendidikan Kimia, Universitas Negeri Gorontalo, Jl. Prof. Dr. Ing. B.J Habibie, Bone Bolango, Gorontalo

\begin{abstract}
ABSTRAK
Penelitian ini bertujuan untuk memanfaatkan gulma siam (Chromolaena odorata L.) sebagai adsorbrn logam timbal. Metode pembuatan arang aktif yang digunakan adalah dehidrasi, karbonisasi, dan aktivasi. Karbon aktif yang diperoleh di karakterisasi untuk mendapatkan arang aktif yang bisa diaplikasikan, selanjutnya dioptimasi. Hasil karakterisasi karbon aktif yang diperoleh memenuhi syarat mutu karbon aktif berdasarkan Standar Industri Indonesia (SII No.0258-88) Uji adsorbsi didapat $\mathrm{pH}$ optimum ion $\mathrm{Pb}^{2+}$. $\left(\mathrm{Pb}\left(\mathrm{NO}_{3}\right)_{2}\right.$ dalam aquades) arang gulma siam teraktivasi $\mathrm{NaOH} 0,2 \mathrm{M}$ pada variasi $\mathrm{pH}(2,3,4,5,6)$ adalah pada $\mathrm{pH} 5$ dengan penyerapan $69,00 \%$. Waktu kontak optimum yang dibutuhkan Waktu kontak optimum yang dibutuhkan terhadap adsorpsi ion $\mathrm{Pb}$ adalah 4 jam pada variasi (1-5 jam) dengan penyerapan 70,19\%. Konsentrasi optimum pada variasi (konsntrasi 20; 40; 60; 80; 100 ppm) pada adsorpsi ion $\mathrm{Pb}$ adalah 100 ppm dengan penyerapan $76,15 \%$. Lama pemanasan optimum pada variasi 1,$5 ; 2 ; 2,5$; dan 3 jam adsorpsi ion $\mathrm{Pb}$ adalah satu jam tiga puluh menit dengan penyerapan sebesar $65,95 \%$. Berdasarkan hasil optimasi maka karbon aktif dari gulma siam yang dibuat dapat digunakan sebagai bahan adsorbsi terhadap cemaran logam berat tim$\operatorname{bal}(\mathrm{Pb})$
\end{abstract}

Kata Kunci : arang aktif; adsorben; gulma siam

\begin{abstract}
This study aims to utilize (Chromolaena odorata L) as a metal adsorbent. The methods used to make activated charcoal are dehydration, carbonization, and activation. The activated carbon is then characterized to obtain activated charcoal that can be applied, then optimized. The results of activated carbon characterization obtained have reached the activated carbon quality requirements based on the Indonesian Industry Standard (SII No. 0258-88). Based on the adsorption test, the optimum pH of $\mathrm{Pb}^{2+}$ (Pb (NO3) 2 (in distilled water) Chromolaena odorata $L$ charcoal activated by $\mathrm{NaOH} 0.2 \mathrm{M}$ under varying $\mathrm{pH}(2,3,4,5,6)$ is at $\mathrm{pH} 5$ with $69.00 \%$ absorption. The optimum contact time required for $\mathrm{Pb}$ ion adsorption is 4 hours at variation (1-5 hours) with $70.19 \%$ absorption. The optimum concentration at variation (concentration 20; 40; 60; 80; $100 \mathrm{ppm}$ ) on $\mathrm{Pb}$ ion adsorption is $100 \mathrm{ppm}$ with $76.15 \%$ absorption. The optimum heating time is a variation of 1.5; 2; 2.5; and 3 hours of Pb ion adsorption is one hour 30 minutes with an absorption of $65.95 \%$. Based on the optimization results, the activated carbon from the Chromolaena odorata $L$ can be used as an adsorption material against the contamination of lead heavy metals (Pb).
\end{abstract}

Keywords: activated charcoal; adsorbent; siam wee

\section{Received: 19-02-2020, Accepted: 07-07-2020, Online: 08-07-2020}

\section{PENDAHULUAN}

Perkembangan dalam bidang industri di Indonesia pada saat ini cukup pesat. Hal ini ditandai dengan semakin banyaknya industri yang memproduksi berbagai jenis kebutuhan manusia seperti industri kertas, tekstil, penyamak kulit, dan sebagainya. Seiring dengan

\footnotetext{
${ }^{*}$ Corresponding author:

ernimohomad@gmail.com
} 
perkembangan industri tersebut, maka semakin banyak pula limbah (hasil sampingan yang diproduksi sebagai limbah). Salah satu limbah tersebut logam berat yang dibuang sebagai limbah. Logam yang dimaksud adalah timbal $(\mathrm{Pb})$, kromium $(\mathrm{Cr})$, kadmium $(\mathrm{Cd})$ dan tembaga $(\mathrm{Cu})$. Limbah ini akan menyebabkan pencemaran serius terhadap lingkungan jika kandungan logam berat yang terdapat didalamnya melebihi ambang batas serta mempunyai sifat racun yang sangat berbahaya dan akan menyebabkan penyakit serius bagi manusia apabila terakumulasi di dalam tubuh.

Beberapa metode kimia maupun biologis telah dicoba untuk mengambil logam berat yang terdapat di dalam limbah, diantaranya adsorpsi, pertukaran ion (ion exchange), dan pemisahan dengan membran. Proses adsorpsi lebih banyak dipakai dalam industri karena mempunyai beberapa keuntungan, yaitu lebih ekonomis dan juga tidak menimbulkan efek samping yang beracun serta mampu menghilangkan bahan-bahan organik (Setyaningtyas, 2005). Menurut Ahmad (2001), adsorpsi adalah proses akumulasi adsorbat pada permukaan adsorben yang disebabkan oleh gaya tarik antar molekul adsorbat dengan permukaan adsorben. Interaksi yang terjadi pada molekul adsorbat dengan permukaan kemungkinan diikuti lebih dari satu interaksi, tergantung pada struktur kimia masing-masing komponen.

Kebanyakan adsorben yang digunakan dalam proses adsorpsi adalah alumina, karbon aktif, silika gel, dan zeolit. Adsorben tersebut mempunyai kemampuan adsorpsi yang baik tetapi tidak ekonomis. Dewasa ini sedang digalakkan penelitian mengenai penggunaan adsorben alternatif yang berasal dari alam, dimana selain memiliki kemampuan adsorpsi yang baik juga bersifat lebih ekonomis (Jalali et al., 2002).

Timbal merupakan salah satu unsur kimia yang terdapat dalam unsur periodik, unsur logam ini memiliki simbol $\mathrm{Pb}$ yang berasal dari bahasa latin Plumbum. Dalam bahasa Indonesia lead biasa disebut dengan timbal. Timbal memiliki sifat fisik, lembut dan mudah dibentuk namun juga berat dan beracun. Unsur akan berwarna putih jika langsung dipotong namun akan tidak berwarna sampai keabu-abuan jika terkena udara. Timbal juga terdapat dari sisa berbagai kegiatan seperti pertambangan, industri dan transportasi merupakan limbah yang tergolong dalam kelompok B3 (Bahan Berbahaya dan Beracun) yang sering ditemukan dalam air, tanah dan udara (Yoma, 2010). Unsur ini juga logam berat yang sangat berbahaya bagi makhluk hidup karena bersifat neurotoxin, yaitu racun yang menyerang saraf dan bersifat karsinogenik, dapat menyebabkan mutasi, terurai dalam jangka waktu yang lama dan tokisisitasnya yang tidak berubah (Novem, 2010).

Masuknya $\mathrm{Pb}$ ke dalam tubuh manusia melalui air minum, makanan atau udara dapat menyebabkan gangguan pada organ seperti gangguan neurologi (syaraf), ginjal, sistem reproduksi, sistem hemopoitik serta sistem syaraf pusat (otak) terutama pada anak yang dapat menurunkan tingkat kecerdasan. Sumber masuknya timbal diperairan yang paling utama berasal dari $\mathrm{Pb}$ di udara yang terbawa oleh angin dan hujan, serta limbah buangan Industri (Ahmad, 2001).

Salah satu adsorben yang menjanjikan adalah limbah organik seperti limbah tanaman jagung, padi, pisang, dan lain-lain. Di antara beberapa limbah organik tersebut yang menarik adalah penggunaan gulma siam. Hal ini disebabkan sifat gulma siam yang rendah nilai gizinya, tahan terhadap pelapukan, memiliki kandungan abu yang tinggi, bersifat abrasif, menyerupai kandungan kayu, serta memiliki kandungan karbon yang cukup tinggi (Danarto, 2007).

Karbon aktif adalah suatu bahan yang berupa karbon amorf yang sebagian besar terdiri dari karbon bebas serta mempunyai kemampuan daya serap (adsorbsi) yang baik. Karbon aktif digunakan sebagai bahan pemucat (penghilang zat warna), penyerap gas, penyerap logam, dan sebagainya. Dari bahan tersebut yang paling sering dipergunakan sebagai bahan adsorben adalah activatedcarbon (Rahayu, 2004). Pemilihan bahan baku dari karbon aktif ditentukan berdasarkan 
besarnya kandungan karbon pada bahan tersebut. Pembuatan karbon aktif berlangsung tiga tahap yaitu proses dehidrasi, proses karbonisasi dan proses aktivasi (Aisah, 2010).

Menurut Sukardjo bahwa molekul-molekul pada permukaan zat padat atau zat cair, mempunyai gaya tarik ke arah dalam, karena tidak ada gaya-gaya yang mengimbangi. Adanya gaya-gaya ini menyebabkan zat padat dan zat cair, mempunyai gaya adsorpsi. Adsorpsi berbeda dengan absorpsi. Pada absorpsi zat yang diserap masuk ke dalam adsorben sedang pada adsorpsi, zat yang diserap hanya pada permukaan (Sukardjo, 2002:190).

Berdasarkan uraian diatas, maka perlu ada bukti yang mendukung terkait potensi gulma siam sebagai penyerap logam berat. Selain itu, potensi gulma siam sebagai penyerap logam berat belum pernah dilakukan. Olehnya itu peneliti tertarik untuk melakukan penelitian yaitu: " Pemanfaatan gulma siam Chromolaena odorata L.) sebagai adsorben pada logam $\mathrm{Pb}$ ".

\section{METODE PENELITIAN}

\section{Tempat dan Waktu Penelitian}

Tempat penelitian adalah di Laboratorium Kimia Fakultas Matematika dan IImu Pengetahuan Alam Universitas Negeri Gorontalo dan waktu penelitian selama 2 bulan.

\section{Bahan Penelitian}

Bahan yang digunakan dalam penelitianini adalah zat aktivator, $\mathrm{NaOH}, \mathrm{Pb}\left(\mathrm{NO}_{3}\right)_{2}, \mathrm{HNO}_{3}$ (p.a), larutan buffer, aquadest. Bahan analisa: Amilum, Natrium tiosulfat, lodium, Metilen blue.

\section{Peralatan}

Alat yang digunakan dalam penelitian adalah gelas piala, gelas ukur, corong, Erlenmeyer, batang pengaduk, $\mathrm{pH}$ meter, neraca analitik, cawan porselin, Kaca arloji, kertas saring, mikro pipet, pipet ukur, pipet tetes, pipet volumetric, furnace, buret, shaker, centrifuge, deksikotor, ayakan vibrator Screen, oven, vial polietilen ukuran $5 \mathrm{ml}$ danspektrofotometer UV-Vis, spektrofotometer serapan atom (SHIMADZU-AA-6200).

\section{Prosedur Kerja \\ Variasi Waktu Kontak}

Variasi ukuran luas media permukaan adsorben dan variasi kecepatan pengadukan, hanya saja waktu kontak yang divariasikan yaitu 1, 2, 3, 4, dan 5 jam. Karbon aktif gulma siam 0,5 g diinteraksikan dengan $50 \mathrm{~mL}$ larutan $\mathrm{Pb}$ secara individual dengan konsentrasi awal $20 \mathrm{ppm}$. Ukuran luas permukaan dan kecepatan pengadukan yang digunakan merupakan hasil yang terbaik yang didapat dari prosedur sebelumnya untuk didapatkan waktu kontak yang terbaik. Kemudian filtrat yang diperoleh dianalisis konsentrasi logam $\mathrm{Pb}$ dengan Spektrofotometer Serapan Atom (SSA).

\section{Variasi pH}

Larutan timbal $25 \mathrm{~mL}$ dengan konsentrasi $20 \mathrm{mg} / \mathrm{L}$ (Radyawati, 2011) dibuat dengan mengencerkan larutan induk, kemudian $\mathrm{pH}$ diatur sebesar 2, 3, 4, 5, 6, atau sampai keruh untuk larutan timbal dengan menambahkan $\mathrm{HNO}_{3}$ atau $\mathrm{NH}_{4} \mathrm{OH}$. Kemudian larutan timbal dicampurkan dengan 0,5g arang hayati aktif (Radyawati, 2011) dalam tabung Erlenmeyer $100 \mathrm{~mL}$, selanjutnya ditutup dengan kertas aluminium foil, diikat dengan karet dan dikocok dalam shaker berputar selama 1 jam. Filtrat yang diperoleh kemudian dianalisis konsentrasi logam $\mathrm{Pb}$ dengan Spektrofotometer Serapan Atom (SSA). 


\section{Variasi Konsentrasi}

Adsorben dengan ukuran partikel $212 \mu \mathrm{m}$ ditimbang masing-masing $0.5 \mathrm{gram}$, lalu ditambahkan larutan ion logam sebanyak $10 \mathrm{~mL}$ dengan variasi konsentrasi $20,40,60$, 80, dan 100 ppm. Variasi ini, kemudian dishaker selama 30 menit dengan kecepatan putaran $180 \mathrm{rpm}$. Setelah itu disaring dan filtrat dihasilkan ditampung dan ditepatkan volumenya $10 \mathrm{~mL}$ dengan aquadest, ditambah 1 tetes asam nitrat dan diukur dengan AAS.

\section{Variasi Lama Pemanasan}

Ditimbang masing-masing 0,5 gram gulma siam dengan ukuran partikel $212 \mu \mathrm{m}$, lalu dipanaskan pada suhu $250^{\circ} \mathrm{C}$ dengan variasi lama pemanasan:1; 1,5; $2 ; 2,5$; dan 3 jam. Lalu ditambahkan larutan ion logam dengan konsentrasi 20 ppm. Kemudian dishaker selama 30 menit dengan kecepatan putaran $180 \mathrm{rpm}$. Setelah itu disaring, dan filtrat yang dihasilkan ditampung dan ditepatkan volumenya $10 \mathrm{~mL}$ dengan aquades. Lalu ditambah 1 tetes asam nitrat p.a dan diukur dengan AAS (SHIMADZU-AA-6200).

\section{HASIL DAN PEMBAHASAN}

\section{Pengaruh Waktu Kontak Terhadap Penyerapan}

Variasi waktu kontak dilakukan untuk mengetahui berapa lama waktu optimum yang dibutuhkan oleh adsorben abu gulma siam untuk mengadsorpsi logam $\mathrm{Pb}$ hingga keadaan kesetimbangan. Waktu kontak merupakan lamanya waktu yang dibutuhkan untuk berinteraksi pada proses adsorpsi gulma siam sebagai adsorben dan logam $\mathrm{Pb}$ sebagai adsorbat. Semakin lama waktu kontak dapat memungkinkan proses difusi dan penempelan molekul adsorbat berlangsung lebih baik (Pujiana, 2014). Gambar 1 menunjukan pengaruh waktu kontak terhadap efesinsi penyerapan terhadap logam timbal.

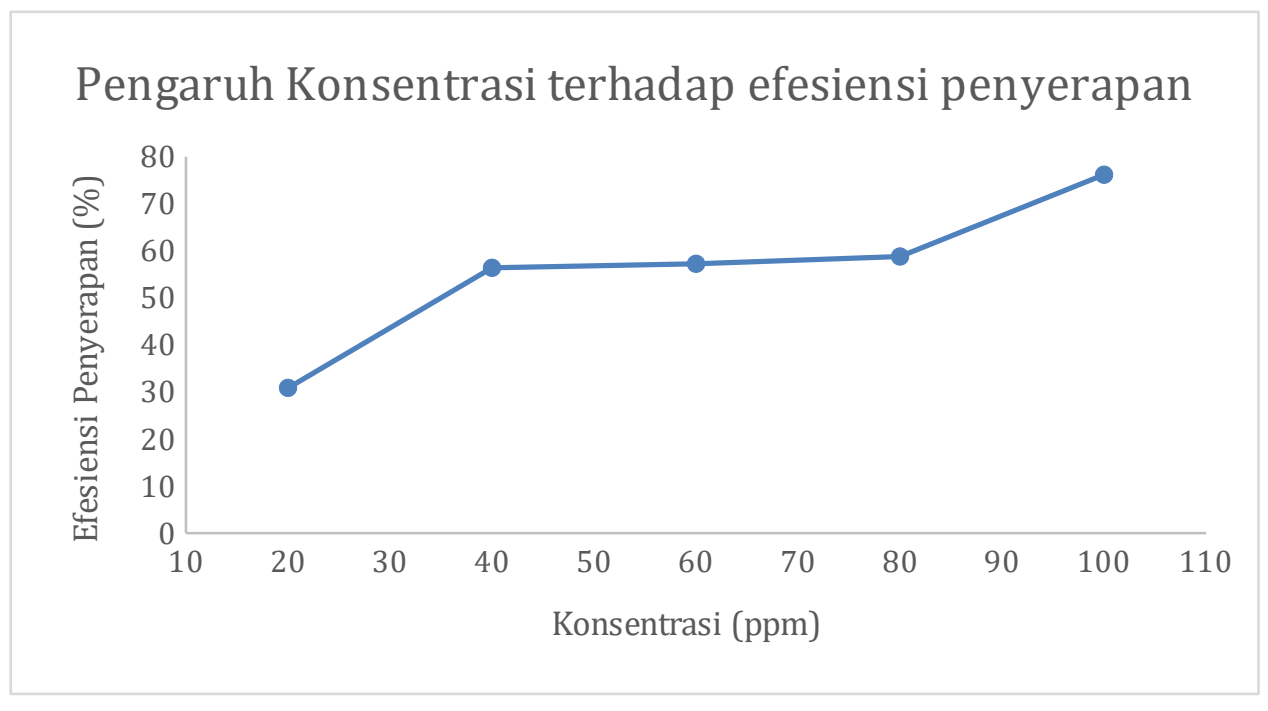

Gambar 1. Hasil variasi waktu kontak terhadap efisiensi peyerapan ion logam $\mathrm{Pb}$

Variasi waktu kontak yang digunakan dalam penelitian ini yaitu 1, 2, 3, 4, dan 5 jam. Penelitian ini dilakukan pada konsentrasi adsorbat $20 \mathrm{ppm}$ dengan massa adsorben $0,5 \mathrm{~g}$ dan kecepatan pengadukan $100 \mathrm{rpm}$ yang digunakan merupakan hasil yang terbaik yang didapat dari prosedur penelitian Falahiyah. Variasi waktu kontak dilakukan karena waktu kontak mempengaruhi kesetimbangan adsorpsi. Waktu kontak dapat mempengaruhi gaya tarik-menarik atau interaksi antara adsorben dan adsorbat seperti gaya Van Der Waals dan gaya elektrostatik.

Dari data yang dihasilkan, kondisi optimum untuk waktu kontak adsorpsi logam $\mathrm{Pb}$ oleh adsorben gulma siam adalah selama 4 jam dengan persentase terserapnya logam $\mathrm{Pb}$ sebesar 
70,19\%. Pada waktu kontak 1 sampai 4 jam presentase adsorpsi mengalami kenaikan karena waktu kontak lebih lama menyebabkan interaksi antara arang aktif gulma siam dengan logam $\mathrm{Pb}$ menjadi lebih besar. Penurunan persentase adsorpsi logam $\mathrm{Pb}$ terjadi pada waktu kontak 5 jam karena pada konsentrasi ini logam $\mathrm{Pb}$ yang terserap pada permukaan arang aktif lebih besar daripada konsentrasi iogam $\mathrm{Pb}$ yang tetap berada dalam larutan, sehingga pada waktu kontak tersebut menyebabkan logam $\mathrm{Pb}$ yang sudah terserap pada arang aktif akan lepas kembali dalam larutan.

\section{Pengaruh pH terhadap Penyerapan logam Timbal(Pb)}

Nilai $\mathrm{pH}$ merupakan salah satu parameter terpenting dalam proses adsorpsi dan dapat mempengaruhi kesetimbangan kimia pada adsorbat maupun pada adsorben. Dalam variasi $\mathrm{pH}$ ini kemungkinan terjadi ikatan kimia antara adsorben dengan adsorbat. Lebih jelasnya dapat dilihat pada gambar 2 berikut.

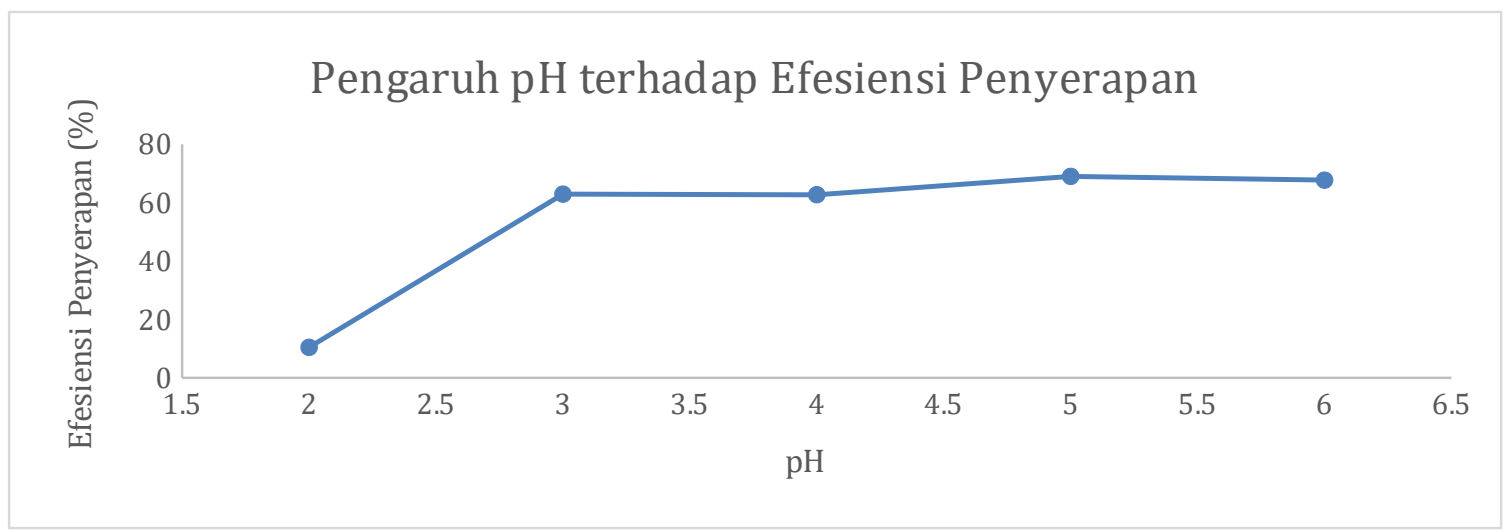

Gambar 2. Hasil variasi $\mathrm{pH}$ terhadap efisiensi penyerapan logam $\mathrm{Pb}$

Dari gambar 2 di atas dapat dilihat proses adsorpsi mengalami peningkatan seiring dengan meningkatnya $\mathrm{pH}$, tetapi mengalami penurunan setelah melewati titik optimum yag dicapai, dimana pada $\mathrm{pH}$ rendah ketersediaan ion $\mathrm{H}^{+}$meningkat. Jumlah ion $\mathrm{H}^{+}$lebih banyak dibandingkan dengan ion $\mathrm{Pb}$ pada $\mathrm{pH}$ rendah, yang menyebabkan ion $\mathrm{H}^{+}$teradsorpsi lebih dahulu dibandingkan ion $\mathrm{Pb}$ sehingga ion $\mathrm{H}^{+}$yang lebih reaktif terhadap arang aktif akan merebut tempat ion $\mathrm{Pb}$ pada saat proses adsorpsi berlangsung. Pada $\mathrm{pH} 5$ terjadi peningkatan adsorpsi hingga mencapai kondisi $\mathrm{pH}$ optimum dimana ketersediaan ion $\mathrm{H}^{+}$berkurang, yang menyebabkan ion $\mathrm{Pb}$ lebih dahulu teradsorpsi. Pada keadaan ini semua sisi aktif pada permukaan arang telah berikatan dengan ion $\mathrm{Pb}$, sedangkan pada $\mathrm{pH} 6$ terjadi penurunan daya adsorpsi. Hal ini dikarenakan, arang aktif telah mencapai titik jenuh dimana pori-pori arang aktif sudah terisi penuh atau terikat seluruhnya dengan ion logam $\mathrm{Pb}$ sehingga tidak dapat mengikat ion logam $\mathrm{Pb}$.

Dari penjelasan diatas dapat diketahui bahwa $\mathrm{pH}$ optimum untuk arang aktif gulma siam adalah $\mathrm{pH} 5$, Nilai $\mathrm{pH}$ optimum arang aktif gulma siam yang menunjukkan konsentrasi ion logam $\mathrm{Pb}$ yang teradsorpsi adalah sebesar $69,00 \%$.

\section{Pengaruh Konsentrasi Terhadap Penyerapan Logam Pb}

Pengaruh konsntrasi terhadap trehadap penyerapan logam timbal dapat dilihat pada gambar 3. Dapat dilihat konsentrasi ion logam terhadap efisiensi penyerapan gulma siam. Dari gambar tersebut terlihat bahwa kondisi optimum penyerapan dicapai pada konsentrasi $100 \mathrm{ppm}$, dengan efisiensi penyerapan untuk ion logam $\mathrm{Pb}$ sebesar $76,15 \%$. Dengan meningkatnya konsentrasi ion logam, efisiensi penyerapan pun menjadi berkurang, dikarenakan kemampuan 
menyerap gulma siam terhadap ion logam berat $\mathrm{Pb}$ sudah maksimum. Dengan kata lain kapasitas serap maksimum gulma siam telah tercapai pada konsentrasi 100 ppm.

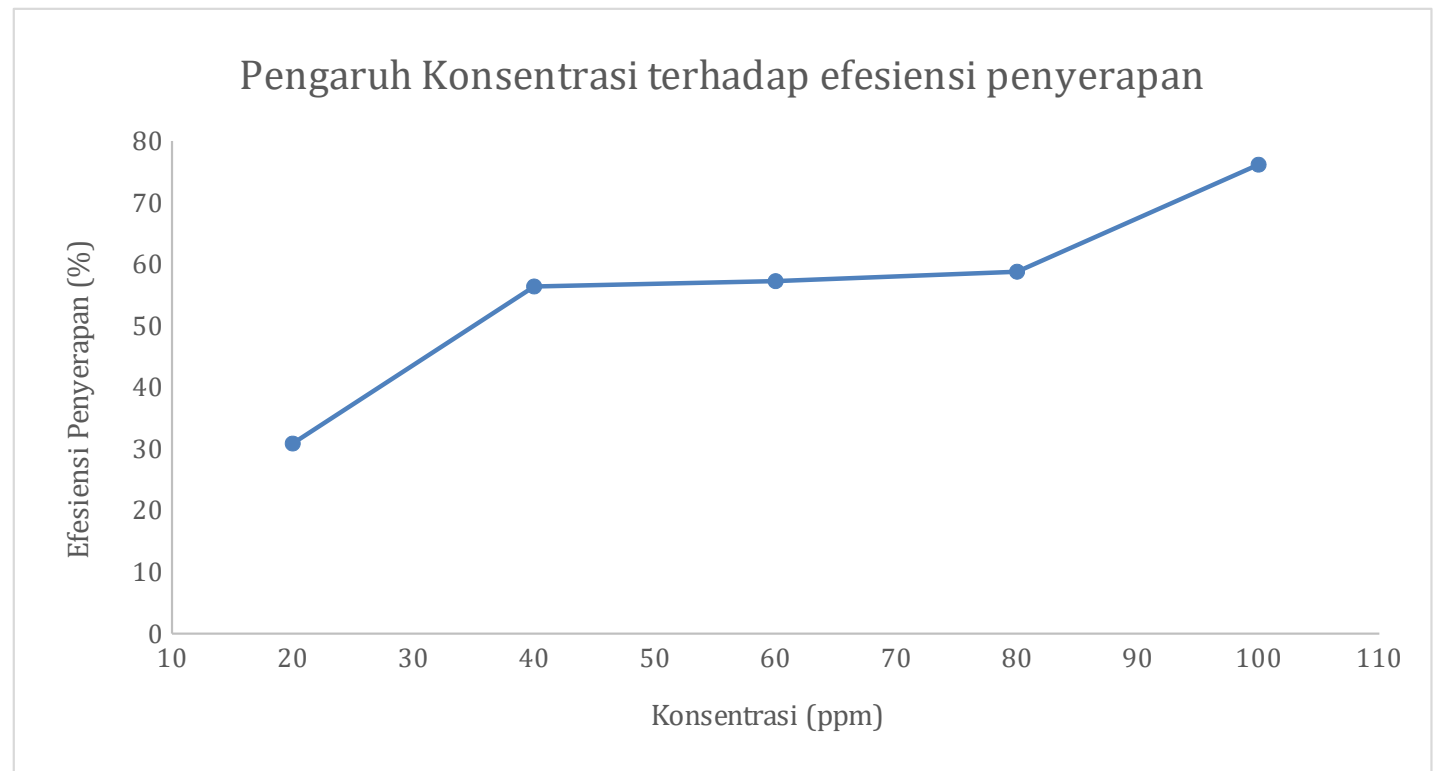

Gambar 3. Konsentrasi ion logam terhadap efisiensi penyerapan ion logam $\mathrm{Pb}$

Menurut Refilda et al., (2001), penurunan efisiensi penyerapan disebabkan karena pada konsentrasi yang lebih tinggi, jumlah ion logam dalam larutan tidak sebanding dengan jumlah pertikel gulma siam yang tersedia sehingga permukaan gulma siam akan mencapai titik jenuh dan efisiensi penyerapan pun menjadi menurun.

Kedua pendapat tersebut sesuai dengan teori Langmuir yang menjelaskan bahwa pada permukaan adsorben terdapat situs aktif yang jumlahnya sebanding terhadap luas permukaan adsorben, sehingga bila situs aktif pada permukaan dinding sel adsorben telah jenuh oleh ion logam, maka penambahan konsentrasi tidak lagi dapat meningkatkan kemampuan adsorpsi dari adsorben tersebut. Oleh sebab itu, pada konsentrasi lebih dari 20 ppm, adsorpsi ion logam mengalami penurunan (Sembiring et al,, 2008).

Menurut Wijayanti (2009) bila permukaan sudah jenuh atau mendekati jenuh terhadap adsorbat, dapat terjadi dua hal: 1. Terbentuk lapisan adsorpsi kedua dan seterusnya di atas adsorbat yang telah terikat di permukaan, gejala ini disebut adsorpsi multilayer. 2. Tidak terbentuk lapisan kedua dan seterusnya sehingga adsorbat yang belum teradsorpsi berdifusi keluar pori dan kembali ke arus fluida.

\section{Pengaruh Lama Pemanasan Ion Logam Terhadap Penyerapan Ion Logam Pb}

Pemanasan adsorben dapat meningkatkan kemampuan penyerapan terhadap adsorbat. Pemanasan yang dilakukan dapat memperbesar pori-pori adsorben sehingga akan meningkatkan efisiensi penyerapan (Nurhasni, 2002). Diketahui bahwa suhu karbonisasi berpengaruh terhadap keaktifan adsorben, semakin tinggi suhu makin rendah daya serapnya. Hasil penelitian menunjukkan karbonisasi gulma siam suhu di atas $250^{\circ} \mathrm{C}$ diperoleh adsorben dengan daya adsorpsi yang sangat rendah. Hal ini dapat dijelaskan karena pada suhu di atas $250^{\circ} \mathrm{C}$ sebagian besar gulma siam diubah menjadi abu gulma siam. Abu gulma siam banyak mengandung senyawa silika. Senyawa ini memiliki daya serap rendah dibandingkan karbon karena kurang pori pada permukaan partikel (Asyar et al., 1996). Lama pemanasan ion logam terhadap penyerapan dapat dilihat pada gambar 4 . 


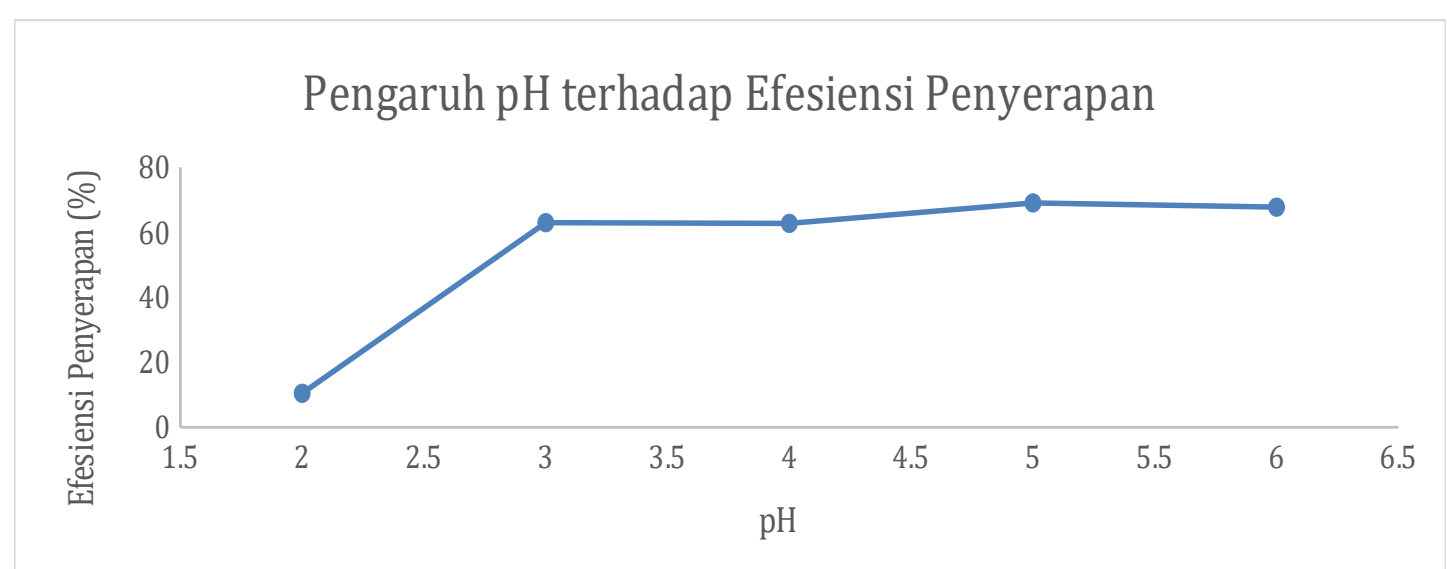

Gambar 4 pengaruh lama pemanasan terhadap efisiensi penyerapan ion logam $\mathrm{Pb}$.

Pada penelitian ini dilakukan proses karbonisasi pada suhu $250^{\circ} \mathrm{C}$ dengan variasi lamanya pemanasan. Dari gambar 4 terlihat bahwa kondisi optimum penyerapan gulma siam rata-rata dicapai pada 3 jam. Sedangkan untuk pemanasan lebih lama lagi efisiensinya mulai menurun, hal ini disebabkan karena terjadinya perubahan struktur dari gulma siam tersebut.

\section{SIMPULAN}

Karakterisasi arang gulma siam tdapat dijadikan sebagai bahan adsorben pada logam $\mathrm{Pb}$. Dengan melihat syarat mutu karbon aktif telah memenuhi Standar Indusri Indonesia (SII No. 0258-88). pH optimum adsorpsi ion $\mathrm{Pb}$ oleh arang gulma siam teraktivasi $\mathrm{NaOH} \mathrm{0,2} \mathrm{M}$ terjadi pada $\mathrm{pH} 5$ dengan penyerapan $69 \%$. Waktu kontak yang dibutuhkan terhadap adsorpsi ion $\mathrm{Pb}$ oleh arang gulma siam teraktivasi $\mathrm{NaOH}$ 0,2 $\mathrm{M}$ adalah 4 jam dengan penyerapan 70,19\%. Konsentrasi $\mathrm{Pb}$ optimum pada adsorpsi ion $\mathrm{Pb}$ oleh arang gulma siam teraktivasi $\mathrm{NaOH}$ adalah 100 ppm dengan penyerapan $76,15 \%$. Lama pemanasan optimum pada adsorpsi ion $\mathrm{Pb}$ oleh arang gulma siam teraktivasi $\mathrm{NaOH} 0,2 \mathrm{M}$ sebesar $65,95 \%$.

\section{DAFTAR PUSTAKA}

Ahmad, M, 2001, Kesetimbangan Adsorpsi Optimal Campuran Biner Cd(II) dan Cr(III) dengan Zeolit Alam Terinpregnasi 2-merkaptobenzotiazol. Jurnal Natur Indonesia., 6(2): 111-117

Asyar, Rayandra., M. Saleh Arif., M. Rusdi., 1996, Diversifikasi Pemanfaatan Padi Sebagai Adsorben $\beta$-karoten pada Pemurnian Minyak Sawit Mentah. Skripsi., Jambi: Universitas Jambi.

Danarto, 2007, Adsorpsi Limbah Logam BeratMultikomponen dengan Karbon dari Sekam Padi, Skripsi., Surakarta:Universitas Sebelas Maret.

Jalali, R., Ghafurian, H., Davarpanah, S.J., and Sepehr, S., 2002, Removal and Recovery of Lead Using Non Living Biomass of Marine Algae, Journal of Hazardous Material B92., 253-262.

Novem N. 2010. Studi Proses Adsorpsi-Desorpsi Ion Logam Pb(II), Cu(II), dan Cd(II) Terhadap Pengaruh Waktu dan Konsentrasi pada Biomassa "Nannochloropsis, sp" yang Terenkapsulasi Aqua-Gel Silika dengan Metode Kontinyu. Prosiding. Seminar Nasional Sains dan Teknologi-Il., Bandar Lampung: Universitas Lampung 
Nurhasni, 2002, Penggunaan Genjer (Limnocharis Flava) Untuk Menyerap Ion Kadmium, Kromium, dan Tembaga Dalam air Limbah, Tesis., Padang: Universitas Andalas.

Pujiana, 2014, Penentuan Waktu Kontak dan pH Optimum Penyerapan Metilen Biru Menggunakan Abu Sekam Padi. J. Molekul. 1(1): 41-44.

Radyawati. (2011). Pembuatan biocharcoal dari kulit pisang kepok untuk penyerapan logam timbal(Pb) dan logam seng(Zn). Palu: UNTAD - Press.

Refilda., Rahmiana Zein., Rahmayeni, 2001, Pemanfaatan Ampas Tebu Sebagai Bahan Alternatif Pengganti Penyerap Sintetik Logam-logam Berat Pada Air Limbah, Skripsi., Padang: Universitas Andalas.

Rahayu, T. 2004 Karbon Aktif Terhadap Penurunan Kadar Mangan. (Mn)

Sembiring, Zipora., Suharso., Regina., Faradila Marta dan Murniyarti. 2008. Studi Proses Adsorpsi-Desorpsi Ion Logam Pb(II), Cu(II), dan Cd(II) Terhadap Pengaruh Waktu dan Konsentrasi pada Biomassa "Nannochloropsis, sp" yang Terenkapsulasi Aqua-Gel Silika dengan Metode Kontinyu. Prosiding. Seminar Nasional Sains dan Teknologi-II., Bandar Lampung: Universitas Lampung.

Setyaningtyas, Tien., Zusfahair., dan Suyata, 2005. Pemanfaatan Abu Sekam Padi Sebagai Adsorben Kadmium (II) dalam Pelarut Air. Majalah Kimia Universitas Jenderal Soedirman., 31(1): 33-41.

Sukardjo., 2002, Arang Aktif dari Ampas Tebu Sebagai Adsorben pada Pemurnian Minyak Goreng Bekas. Skripsi., Bogor: Institut Pertanian Bogor.

Wijayanti, Ria., 2009, Arang Aktif dari Ampas Tebu Sebagai Adsorben pada Pemurnian Minyak Goreng Bekas. Skripsi., Bogor: Institut Pertanian Bogor.

Yoma K, 2010, Penggunaan Genjer(Limnocharis Flava) Untuk Menyerap Ion Kadmium, Kromium, dan Tembaga Dalam air Limbah, Tesis., Padang: Universitas Andalas. Riapanitra, Anung., T. Setyaningtyas dan $\mathrm{K}$. 